\title{
Project Management's Triple Constraints Mapping on Augmented Reality based Learning System for Improved Quality
}

\author{
Mehreen Sirshar \\ faculty of software engineering \\ fatima jinnah women university \\ Rawalpindi, Pakistan \\ mehreensirshar@fjwu.edu.pk
}

\author{
Syeda Hafsa Ali \\ dept. of software engineering \\ fatima jinnah women university \\ Rawalpindi, Pakistan \\ hafsaali1803@gmail.com
}

\author{
Haleema Sadia Baig \\ dept. of software engineering \\ fatima jinnah women university \\ Rawalpindi, Pakistan \\ haleemabaig7@gmail.com
}

\begin{abstract}
Over the last few decades there has been an exponential growth in IT, motivating IT professionals and scientists to explore new dimensions resulting in the advancement of artificial intelligence and its subcategories like computer vision, deep learning and augmented reality. AR is comparatively a new area which was initially explored for gaming but recently a lot of work has been done in education using AR. Most of this focuses on improving students understanding and motivation. Like any other project, the performance of an AR based project is determined by the customer satisfaction which is usually affected by the theory of triple constraints; cost, time and scope. many studies have shown that most of the projects are under development because they are unable to overcome these constraints and meet project objectives. We were unable to find any notable work done regarding project management for augmented reality systems and application. Therefore, in this paper, we propose a system for management of AR applications which mainly focuses on catering triple constraints to meet desired objectives. Each variable is further divided into subprocesses and by following these processes successful completion of the project can be achieved.
\end{abstract}

Index Terms-triple constraints, augmented reality, Augmented reality-based learning systems, time, cost, scope, artificial intelligence, education.

\section{INTRODUCTION}

Augmented reality can be defined as computer generated content tied with real world in a specific fraction. This content can be in the form of text, graphics, animations and videos projected onto user's real world. Augmented reality is often confused with virtual reality and mixed reality but in AR, user's frame of reference is tied to real world in such a way that virtual objects are superimposed as if they coexist at one place. It can be considered as "middle ground" between virtual reality and actual reality. According to Azuma and other researchers [1], Augmented reality is identified on the basis of three characterized features:

1. Real and virtual world combination

2. Interactive virtual objects in real time domain3. Super imposed virtual objects must be3-dimensional. AR has a lot of potential applications to be explored in various fields be it medical visualization, repair and maintenance, military aircraft navigation or entertainment but still there is a large development gap between AR and VR, needed to be filled.
AR applications can fall into three major categories: "Information visualization", "Industry" and "Edutainment".

In education it can be used to engage and motivate students, improve teacher and student communication during lectures. Steve Chi Yi Yuan [2] has identified five potential directions for Augmented Reality in Education which are; AR books, AR games, object modeling, discovery-based learning programs and particular skills training. Such systems can easily be developed using AR tools available for both Web based applications and mobile applications, like SDKs, ZOOBRUST and Unity. Over the past few years various AR based systems are developed to improve educational facilities yet there is a serious need to design and develop learning activities using augmented reality[3]. In order to implement an AR based learning system different tools and techniques of Project management can come into action. Term Project management can be defined as "the application of knowledge, skills, tools and techniques to project activities to meet project requirements." [4]

As stated in PMBOK, every year almost one quarter of total gross domestic product of united states is spend on projects and the whole world spends nearly 10 trillionofits 40.7 gross product on different types of projects. [4]

IT based projects have a higher failure record as compare to other domains.

According to a study done by CHAOS, only 16.2 percent of all the IT companies were able to meet their triple constraints in U.S during 1995.and out of these 31 percent were forced to drop in execution face due to over cost.[5]

Knowledge areas are an important part of Project management and describe the key competencies that project managers must develop. Out of ten knowledge areas, four are defined as core areas i.e triple constraints and other Four knowledge areas are called facilitating areas which help in achieving project objectives. One knowledge area (project integration management) affects and is affected by all of the other knowledge areas.

The first knowledge area is Project scope management that define and manage all the word needed for successful project 
completion. Project time management provide an estimated time for project completion. Project cost management estimate the budget while Project quality management ensures that the project will fulfil user requirements as well as follows all the standards. Project HR management deals with effective use of human resources connected with projects. Project communications management involves generating, collecting, disseminating, and storing project information. In risk management a manger identifies, analyze, and respond to risks related to the project. While procurement involves utilization of help from a third party. As name suggest in Project stakeholder management stakeholder identification and analyzation is done while monitoring and managing the overall project. Integration management is an overlapping function that is related to all the other knowledge areas Project management and its knowledge areas implementation plays key role in the successful completion of a project. In this paper a scheme is proposed to implement four core knowledge areas; time, scope, cost and quality management to achieve project specific objectives for an augmented realitybased student learning and feedback system

\section{LITERATURE REVIEW}

Manola m.o. desilva [6] supervised a systematic review on how the impact of augmented reality in education has been evaluated over time. The study followed PRISMA protocol for analyzing the papers. Most of the papers analyzed showed a positive response towards Augmented reality insertion in education while some discussed the shortcomings which students and lecturer may face.

A study conducted by Stefanos Giasiranis et al [7] in 2016 investigated whether augmented reality or web-based technology can improve student's performance in the class by teaching a module to a junior high school class. Results obtained from the experiment have shown visible signs of improvement in students with AR technology.

Carol A Brewer [8] in his paper explained about two types of instructional technology tools being used for better understanding of students and evaluation of teaching practices particularly in biology. Two instructional technology tools used for this purpose are:

- off the shell personal response system (PRS)

- custom designed web-based assessment (Bio-Bytes) Overall response to this system was quite good and it actually strengthen the teacher student communication. However, as stated in the paper, there are some instructional challenges to fully implement these systems in class room environments because either the instructor are not professionally trained or they find it difficult to balance between exposing students to use technology with its full capabilities and find the time for class discussions.

According to Matt Dunleavy et al. [9], a study was conducted to document students and teacher's behavior towards AR simulation used for teaching and learning. These studies were conducted across the students of 6th, 7th and high schoolers and the data collected has shown that AR simulation has given highly engaging results from students. However, some technological and cognitive challenges were noticed.

In "ALFS to support teacher and learner communication", Zarraonandia et al. [10] explain the development of an Augmented reality-based lecture feedback system which could be used to improve communication between the lecturer and students particularly during the lecture. A study was conducted to determine the success or failure of the system has shown positive results in gathering private and immediate response from the students during lecture.

To cater the needs of ever-increasing students with limited resources, Naemi Luckver et al. [11] has designed an online teaching and learning tool "Aarora". Another similar webbased project [12]; "Active class project" was developed to increase in-class participation. This system requires students to use personal wireless devices to participate. The system tested on three large classes showed a significant increase in class participation. To increase student involvement and interest in class an AR tool "Ariane"; to guide augmented reality leaning activities [13] is being developed.

Grald Bertrom [14] explains the use of "clickers"; a system which shows students response on screen through wireless remote devices. These systems are able to combine text, graphic, audio and video components thus enhancing student's critical thinking and collaborative thinking abilities. "Audience Response System" or better known as "Clickers" is a tool developed by Jane E CaldWell [15] to engage students in a large class. These handheld devices are used by students to transmit answer by pressing buttons. Moreover "clickers" can be used for attendance, communication or prevent frustration. At the end of the lecture ARS allows lecturer to visualize overall response of the students towards the lecture by showing a progress histogram. In previous papers, Its' been suggested that use of electronic voting or response system contributes to students overall performance but to check the association between student's use of EVS and performance in the assessment task, a research was conducted by G.E Kennedy et al. [16] has shown that the performance in end of the semester assessment is associated with correctness of student's EVS response throughout the semester.

Use of augmented reality in education is still in development stages. With the boom of $A R, V R$ and MR; a number of $A R$ based student's response systems have been developed. Little to none of these systems have use or documented their use of "Project Management Knowledge Areas" to implement these systems. It has been proved through various studies that projects which are implemented following ten knowledge areas of project management have a higher success rate.

According to the paper [17] published in 2012, "PMBOK" is a standard body which has defined five process groups and ten 
knowledge areas as the key elements for management of any project. To determine which of these knowledge areas most important for determining the success or failure of project an online survey was conducted. The results have shown that scope, time and cost management are critical for project success. Ofer Zwikael [18] explains the importance of knowledge areas during the planning phase of any project. Throughout the project planning; time, scope, risk and human resource management are most influential in determining the project success however it may vary with the nature of project. Although a lot of work has been done with reference to project management but there is a long track record of projects which have underperformed [19]. Most of the projects have shown underperformance either due to wrong estimate of time or has overrun cost. [20]. A survey conducted by IBM, has shown that when managing change in a project only $40 \%$ of the total projects were able to fulfill triple constraints [21]. Moreover, a study conducted on 1,471 IT projects has shown that every one in six projects had a $200 \%$ and $70 \%$ overrun in cost and schedule [22]. Similarly in 2013, a study conducted by the Standish Group found that $43 \%$ of projects were either late or overrun cost and even if completed, all the required features were not included, and $18 \%$ of projects either got cancelled prior to its delivery or if get delivered they were never used [23]. A study conducted in 2012, data from 5400 large IT projects was analyzed which showed that on average value, $45 \%$ of them run project budget while $7 \%$ of them did not get completed in estimated time period[24]. In 2012 Price Waterhouse Coopers, conducted a survey including projects from 34 industries spread across 38 countries and found that $86 \%$ of the projects were unable to fulfill their triple constrains along with quality and benefits baseline [25].

\section{Methodology}

According to the theory of triple constraints; it is a triangle of time, cost and scope which define the quality of a project. The theory signifies that for the development of an augmented reality application, one of the triple constraint variable must have the tendency to be constraint or exploited else it will impact the quality of the deliverable., the project manager has to make a trade off.

As per our research and studies within our limited resources we were unable to find any research work or a study with a framework catering the triple constrains for an augmented reality application. Therefore, we have designed a conceptual framework identifying the relationship between independent and dependent variable in our project and then mapped each one of the triple constrains separately for an AR application showing how they can be designed and developed from a project manager's perspective. Also which processes and tools can be used for successful development of an AR project and then analyze their impact on the overall management of $A R$ project. Wayngaad et al [26], identified the relationship

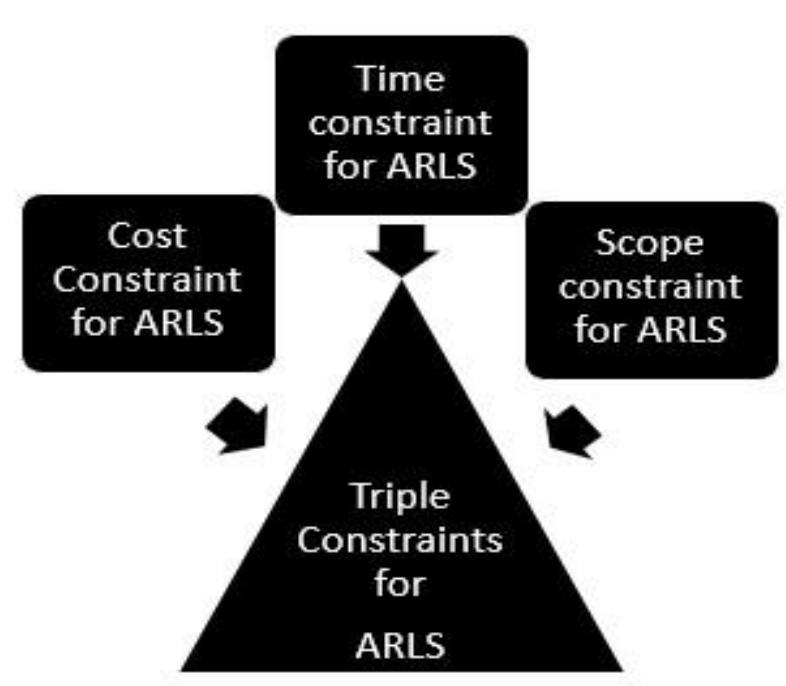

Fig. 1. Triple Constraints of ARLS.

between the three variable of triple constrains, the relationship is elaborated as equations stated below:

- $\mathrm{S} \alpha \mathrm{TC}$

- $\mathrm{T} \alpha \mathrm{S} / \mathrm{C}$

- $\mathrm{C} \alpha \mathrm{S} / \mathrm{T}$

Here $S, T$ and $C$ are scope, time and cost respectively.

\section{A. Cost Management in AR-based Education}

Almost all the projects have a predefined budget and AR based application are no exception. It is also a key variable which can affect the overall project development in a negative manner since it means reduction in project scope.As, Cost is key element in the theory of triple constraints. In order to broaden the scope of the project or shorten the time frame more resources are to be invested thus increasing the cost.

[27],[28],[29],[30],[31].

For an AR application, the project manager ensures the project completion within the approved budget. It is sub divided into four processes: (a) Cost management planning (b) Cost estimation (c) Budgeting (d) Cost Control

Cost management planning involves planning for project cost planning, execution and controlling.

Table 1 explain the inputs, processes and outputs for cost estimation, budgeting and cost control of cost management processes during the project's life cycle.

TABLE I

COST MANAGEMENT PROCESSES MAPPING

\begin{tabular}{|l|l|l|l|l|}
\hline Process & Explanation & Input & Output & $\begin{array}{l}\text { Tools and } \\
\text { Technique }\end{array}$ \\
\hline \multicolumn{6}{|c|}{ Continued to next page } \\
\hline
\end{tabular}




\begin{tabular}{|c|c|c|c|c|}
\hline \multicolumn{5}{|c|}{ Continued from previous page } \\
\hline $\begin{array}{l}\text { Cost } \\
\text { Estimate } \\
\text {-on }\end{array}$ & $\begin{array}{l}\text { Estimates } \\
\text { Cost } \\
\text { Resource }\end{array}$ & $\begin{array}{l}\text { Scope } \\
\text { baseline, } \\
\text { project } \\
\text { schedule, HR } \\
\text { plan, risk } \\
\text { register }\end{array}$ & $\begin{array}{l}\text { Activity cost } \\
\text { estimate, } \\
\text { Basis of } \\
\text { estimates, } \\
\text { project } \\
\text { document } \\
\text { update }\end{array}$ & $\begin{array}{l}\text { Reserve } \\
\text { analysis, cost } \\
\text { of quality, } \\
\text { vendor bid } \\
\text { analysis, } \\
\text { analogous, } \\
\text { parametric, } \\
\text { bottom up } \\
\text { and } \\
\text { three-point } \\
\text { estimate }\end{array}$ \\
\hline $\begin{array}{l}\text { Budgeti- } \\
\text { ng }\end{array}$ & $\begin{array}{l}\text { Identify } \\
\text { Overall cost } \\
\text { of project }\end{array}$ & $\begin{array}{l}\text { Cost estimate } \\
\text { per task, basis } \\
\text { of estimates, } \\
\text { scope } \\
\text { baseline, con- } \\
\text { tracts, } \\
\text { resource } \\
\text { calendar }\end{array}$ & $\begin{array}{l}\text { Cost } \\
\text { performance } \\
\text { baseline, } \\
\text { funding } \\
\text { requirements } \\
\text { and document } \\
\text { update }\end{array}$ & $\begin{array}{l}\text { Cost } \\
\text { aggregation, } \\
\text { reserve } \\
\text { analysis, } \\
\text { historical } \\
\text { relationships }\end{array}$ \\
\hline $\begin{array}{l}\text { Control } \\
\text { and } \\
\text { monitor } \\
\text { cost }\end{array}$ & $\begin{array}{l}\text { Monitor } \\
\text { and cater } \\
\text { changes } \\
\text { in project } \\
\text { budget }\end{array}$ & $\begin{array}{l}\text { Project } \\
\text { management } \\
\text { plan, funding } \\
\text { requirements, } \\
\text { work } \\
\text { performance } \\
\text { information }\end{array}$ & $\begin{array}{l}\text { Cost } \\
\text { forecast, } \\
\text { change } \\
\text { request, work } \\
\text { performance } \\
\text { measurement } \\
\text {, project } \\
\text { management } \\
\text { plan and } \\
\text { document } \\
\text { updates }\end{array}$ & $\begin{array}{l}\text { Earned value } \\
\text { managemet, } \\
\text { forecasting, } \\
\text { to-complete } \\
\text { performance } \\
\text { index, } \\
\text { variance } \\
\text { analysis }\end{array}$ \\
\hline
\end{tabular}

\section{B. Time Management}

For the development of an augmented reality based learning system, time management is the most critical variable. Since time has minimum flexibility, it can cause a number of conflicts during project life cycle.

The total time needed for the completion of a project can be estimated using a number of methods. One of the method is explained below that identifies and prioritizes necessary tasks. It is further divided into seven sub processes. These processes identify crucial activities, relationship between those activities and time duration required for activity completion to design project schedule. Mutual dependency between the tasks and limited resources can stretch the production time. As time is the least flexible commodity, reducing it will affect the cost and scope of project .

TABLE II

TIME MANAGEMENT PROCESSES MAPPING

\begin{tabular}{|l|l|l|l|l|}
\hline Process & Explanation & Input & Output & $\begin{array}{l}\text { Tools and } \\
\text { Technique }\end{array}$ \\
\hline $\begin{array}{l}\text { Defining } \\
\text { tasks }\end{array}$ & $\begin{array}{l}\text { Scope } \\
\text { baseline, } \\
\text { enterprise } \\
\text { environmental } \\
\text { factors, or- }\end{array}$ & $\begin{array}{l}\text { Identify } \\
\text { cruicial } \\
\text { activities }\end{array}$ & $\begin{array}{l}\text { Activity } \\
\text { list, } \\
\text { activity } \\
\text { attributes }\end{array}$ & $\begin{array}{l}\text { Rolling wave } \\
\text { planning, } \\
\text { templates, } \\
\text { decompos- } \\
\text { ition }\end{array}$ \\
\hline
\end{tabular}

\begin{tabular}{|c|c|c|c|c|}
\hline & $\begin{array}{l}\text { ganizational } \\
\text { process assets }\end{array}$ & & $\begin{array}{l}\text { milestone } \\
\text { list }\end{array}$ & \\
\hline $\begin{array}{l}\text { Sequencing } \\
\text { tasks }\end{array}$ & $\begin{array}{l}\text { Activity list, } \\
\text { activity } \\
\text { attributes, } \\
\text { milestone list, } \\
\text { project scope } \\
\text { statement, } \\
\text { organizational } \\
\text { process assets }\end{array}$ & $\begin{array}{l}\text { Document } \\
\text { Relationsh- } \\
\text { ip between } \\
\text { tasks }\end{array}$ & $\begin{array}{l}\text { Project } \\
\text { schedule } \\
\text { network } \\
\text { diagrams, } \\
\text { project } \\
\text { document } \\
\text { updates }\end{array}$ & $\begin{array}{l}\text { Precedence } \\
\text { diagramming } \\
\text { method, } \\
\text { dependency } \\
\text { determinati- } \\
\text { on, schedule } \\
\text { network } \\
\text { template }\end{array}$ \\
\hline $\begin{array}{l}\text { Estimating } \\
\text { task } \\
\text { resources }\end{array}$ & $\begin{array}{l}\text { Activity list and } \\
\text { attributes, } \\
\text { resource } \\
\text { calendar, } \\
\text { organizational } \\
\text { process assets }\end{array}$ & $\begin{array}{l}\text { Define } \\
\text { resource } \\
\text { use per } \\
\text { team to } \\
\text { perform } \\
\text { project } \\
\text { activities }\end{array}$ & $\begin{array}{l}\text { Resource } \\
\text { requireme- } \\
\text { nts, } \\
\text { resource } \\
\text { breakdown } \\
\text { structure, } \\
\text { project } \\
\text { document } \\
\text { update }\end{array}$ & $\begin{array}{l}\text { Alternative } \\
\text { analysis, } \\
\text { bottom-up } \\
\text { estimating, } \\
\text { project } \\
\text { management } \\
\text { software }\end{array}$ \\
\hline $\begin{array}{l}\text { Estimating } \\
\text { task } \\
\text { timeline }\end{array}$ & $\begin{array}{l}\text { Tasks list and } \\
\text { attributes, } \\
\text { task resource } \\
\text { requirements, } \\
\text { resource } \\
\text { calendar and } \\
\text { scope statement }\end{array}$ & $\begin{array}{l}\text { Estimate } \\
\text { number } \\
\text { of work } \\
\text { Periods for } \\
\text { individual } \\
\text { activities }\end{array}$ & $\begin{array}{l}\text { Activity } \\
\text { duration } \\
\text { estimates }\end{array}$ & $\begin{array}{l}\text { Analogous, } \\
\text { parametric, } \\
\text { and three } \\
\text { point } \\
\text { estimate, } \\
\text { reserve } \\
\text { analysis }\end{array}$ \\
\hline $\begin{array}{l}\text { Schedule } \\
\text { developm- } \\
\text { ent }\end{array}$ & $\begin{array}{l}\text { Schedule } \\
\text { network } \\
\text { diagram, activity } \\
\text { list, attributes } \\
\text { and resource } \\
\text { requirements, } \\
\text { task duration } \\
\text { estimate }\end{array}$ & $\begin{array}{l}\text { Analyze } \\
\text { all the } \\
\text { above } \\
\text { defined } \\
\text { processes } \\
\text { and } \\
\text { develop } \\
\text { project } \\
\text { schedule }\end{array}$ & $\begin{array}{l}\text { Schedule } \\
\text { baseline, } \\
\text { schedule } \\
\text { data, } \\
\text { project } \\
\text { calendars }\end{array}$ & $\begin{array}{l}\text { Network } \\
\text { analysis, } \\
\text { Critical path } \\
\text { and chain } \\
\text { methods, } \\
\text { resource } \\
\text { leveling, } \\
\text { schedule } \\
\text { tool, } \\
\text { schedule } \\
\text { compressi- } \\
\text { on }\end{array}$ \\
\hline $\begin{array}{l}\text { Schedule } \\
\text { controlling }\end{array}$ & $\begin{array}{l}\text { Project } \\
\text { schedule and } \\
\text { management } \\
\text { plan, work } \\
\text { performance } \\
\text { information }\end{array}$ & $\begin{array}{l}\text { Control } \\
\text { and } \\
\text { manage } \\
\text { the } \\
\text { changes }\end{array}$ & $\begin{array}{l}\text { Work } \\
\text { performa- } \\
\text { nce } \\
\text { measure- } \\
\text { ments, } \\
\text { Change } \\
\text { requests }\end{array}$ & $\begin{array}{l}\text { Performan- } \\
\text { ce reviews, } \\
\text { variance } \\
\text { analysis, } \\
\text { project } \\
\text { management } \\
\text { software }\end{array}$ \\
\hline
\end{tabular}

\section{Scope Management}

In the development of an AR application the Project scope defines the overall purpose including the end product or final accomplishment. The scope management also determines the quality of the project, which can in return impact the cost and time of the project or vice versa.

Project scope management identify and defines all the processes involves for the development of a certain product at the end of the project. It comprises of six main processes which control overall scope of the project.

TABLE III

SCOPE MANAGEMENT PROCESSES MAPPING 


\begin{tabular}{|c|c|c|c|c|}
\hline Process & Explanation & Input & Output & $\begin{array}{l}\text { Tools and } \\
\text { Technique }\end{array}$ \\
\hline $\begin{array}{l}\text { Require- } \\
\text { ment } \\
\text { collection }\end{array}$ & $\begin{array}{l}\text { Project } \\
\text { charter, } \\
\text { stakeholder } \\
\text { register }\end{array}$ & $\begin{array}{l}\text { Document } \\
\text { the product } \\
\text { features } \\
\text { and } \\
\text { processes } \\
\text { used }\end{array}$ & $\begin{array}{l}\text { Requirement } \\
\text { documentat- } \\
\text { ion and } \\
\text { Traceability } \\
\text { matrix }\end{array}$ & $\begin{array}{l}\text { Interviews, } \\
\text { surveys and } \\
\text { questionnair } \\
\text { e-es, group } \\
\text { creativity } \\
\text { and decision } \\
\text { making } \\
\text { techniques }\end{array}$ \\
\hline $\begin{array}{l}\text { Define } \\
\text { Scope }\end{array}$ & $\begin{array}{l}\text { Requirement } \\
\text { documentatio } \\
\mathrm{n}, \quad \text { project } \\
\text { charter, or- } \\
\text { ganizational } \\
\text { process assets }\end{array}$ & $\begin{array}{l}\text { Review } \\
\text { project } \\
\text { charter, } \\
\text { requiremen } \\
\text { ts and other } \\
\text { documents }\end{array}$ & $\begin{array}{l}\text { Scope } \\
\text { statement, } \\
\text { Document } \\
\text { updates }\end{array}$ & $\begin{array}{l}\text { Product } \\
\text { analysis, } \\
\text { facilitated } \\
\text { workshops, } \\
\text { expert } \\
\text { judgement. }\end{array}$ \\
\hline $\begin{array}{l}\text { WBS } \\
\text { creation }\end{array}$ & $\begin{array}{l}\text { Scope } \\
\text { statement, } \\
\text { requirement } \\
\text { documentation, } \\
\text { organizational } \\
\text { process assets }\end{array}$ & $\begin{array}{l}\text { Project } \\
\text { deliverables } \\
\text { division into } \\
\text { smaller } \\
\text { components }\end{array}$ & $\begin{array}{l}\text { WBS, WBS } \\
\text { dictionary, } \\
\text { Scope } \\
\text { baseline }\end{array}$ & $\begin{array}{l}\text { Decompositi- } \\
\text { on. }\end{array}$ \\
\hline $\begin{array}{l}\text { Scope } \\
\text { Verificat } \\
\text { i-on }\end{array}$ & $\begin{array}{l}\text { Project } \\
\text { management } \\
\text { plan, } \\
\text { requirement } \\
\text { documentation, } \\
\text { traceability } \\
\text { matrix, validate } \\
\text { deliverables }\end{array}$ & $\begin{array}{l}\text { Verify } \\
\text { products } \\
\text { against } \\
\text { deliverables } \\
\text { acceptance } \\
\text { criteria }\end{array}$ & $\begin{array}{l}\text { Accepted } \\
\text { deliverables, } \\
\text { change } \\
\text { requests, } \\
\text { project } \\
\text { document } \\
\text { updates }\end{array}$ & Inspection \\
\hline $\begin{array}{l}\text { Scope } \\
\text { monitori } \\
\text {-ng and } \\
\text { control }\end{array}$ & $\begin{array}{l}\text { Project } \\
\text { management } \\
\text { plan, work } \\
\text { performance } \\
\text { information, } \\
\text { requirement } \\
\text { documentation } \\
\text { and } \\
\text { traceability } \\
\text { matrix }\end{array}$ & $\begin{array}{l}\text { Monitor } \\
\text { changes in } \\
\text { project } \\
\text { scope }\end{array}$ & $\begin{array}{l}\text { Organization } \\
\text { al process } \\
\text { assets } \\
\text { updates, } \\
\text { project } \\
\text { management } \\
\text { plan } \\
\text { updates, } \\
\text { Work } \\
\text { performance } \\
\text { measureme- } \\
\text { nts }\end{array}$ & $\begin{array}{l}\text { Variance } \\
\text { analysis }\end{array}$ \\
\hline
\end{tabular}

IV. DISCUSSION AND CONCLUSION

To summarize the discussion it can be stated that the Project Management Book of Knowledge (PMBOK) and other such books states that for the successful completion of any project (in this case, AR based applications), the final product must match with the user requirements and to get the desired result the project manager has to efficiently deal with triple constraints.

Although the constraints vary from project to project within industry or outside of it but poor design and site conditions, budgeting issues like payment delays and weak financial background of the customer or company are the main causes of time overruns. Similarly, cost overruns can be caused due to extra cost needed for materials, poor planning and selection of cost estimation and inflation which can affect the material and labor cost. The major problems with the scope delivery are a combination of time and cost related issues caused by the client or due to mismanagement by the contractor. It includes limited funding from client or financial mismanagement by the company thus restricting the scope, inadequate planning and supervision by the company can also affect the overall scope of the project.

In conclusion, it can be stated that like any other project for an Augmented Reality learning system triple constraints are crucial and there is always a trade off between these three at the stake of quality of the product. Out of the three constraints, time is the most crucial but if proper planning is done by following the method discussed in the paper or following any other technique the project manager can meet the triple constraints.

In future we would map the knowledge areas of project management for the implementation of AR learning system and would analyze its impact on overall quality of the product.

\section{REFERENCES}

[1] Azuma, R. T. (1997). A survey of augmented reality. Presence: Teleoperators \& Virtual Environments, 6(4), 355-385.

[2] Yuen, S. C. Y., Yaoyuneyong, G., \& Johnson, E. (2011). Augmented reality: An overview and five directions for $A R$ in education. Journal of Educational Technology Development and Exchange (JETDE), 4(1), 11.

[3] Kesim, M., \& Ozarslan, Y. (2012). Augmented reality in education: current technologies and the potential for education. Procedia-Social and Behavioral Sciences, 47, 297-302.

[4] PMI, A Guide to the Project Management Body of Knowledge (PMBOK ${ }^{\circledR}$ Guide) (2004), p. 5.

[5] The Standish Group, "The CHAOS Report" (www.standishgroup.com) (1995). Another reference is Johnson, Jim, "CHAOS: The Dollar Drain of IT Project Failures," Application Development Trends (January 1995).

[6] da Silva, M. M., Teixeira, J. M. X., Cavalcante, P. S., \& Teichrieb, V. (2019). Perspectives on how to evaluate augmented reality technology tools for education: a systematic review. Journal of the Brazilian Computer Society, 25(1), 3.

[7] Giasiranis, S.,\& Sofos, L. (2016). Production and evaluation of educational material using augmented reality for teaching the module of "representation of the information on computers" in junior high school. Creative Education, 7(09), 1270-1291.

[8] Brewer, C. A. (2004). Near real-time assessment of student learning and understanding in biology courses. BioScience, 54(11), 1034-1039.

[9] Dunleavy, M., Dede, C., \& Mitchell, R. (2009). Affordances and limitations of immersive participatory augmented reality simulations for teaching and learning. Journal of science Education and Technology, $18(1), 7-22$.

[10] Zarraonandia, T., Aedo, I., D'laz, P., \& Montero, A. (2013). An augmented lecture feedback system to support learner and teacher communication. British Journal of Educational Technology, 44(4), 616-628.

[11] Purgathofer, P., \& Luckner, N. (2014). Aurora-Exploring Social Online Learning Tools Through Design. In TBP: Proceedings of The Seventh International Conference on Advances in Computer-Human Interactions, $\mathrm{ACHI}$.

[12] Ratto, M., Shapiro, R. B., Truong, T. M., \& Griswold, W. G. (2003). The activeclass project: Experiments in encouraging classroom participation. In Designing for change in networked learning environments (pp. 477486). Springer, Dordrecht.

[13] Alvarez, V., Perez-P' erez, J. R., Paule, M., \& de Freitas, S. (2016).' Ariane: a web-based and mobile tool to guide the design of augmented reality learning activities. Mobile Learning Futures-Sustaining Quality Research and Practice in Mobile Learning, 33. 
[14] Bergtrom, G. (2006). Clicker sets as learning objects. Interdisciplinary Journal of E-Learning and Learning Objects, 2(1), 105-110.

[15] Caldwell, J. E. (2007). Clickers in the large classroom: Current research and best-practice tips. CBE-Life Sciences Education, 6(1), 9-20.

[16] Kennedy, G. E., \& Cutts, Q. I. (2005). The association between students' use of an electronic voting system and their learning outcomes. Journal of computer assisted learning, 21(4), 260-268.

[17] Varajao, J., Colomo-Palacios, R., \& Silva, H. (2017). ISO 21500: 2012 and PMBoK 5 processes in information systems project management. Computer Standards \& Interfaces, 50, 216-222.

[18] Zwikael, O. (2009). The relative importance of the PMBOK ${ }^{\circledR}$ Guide's nine Knowledge Areas during project planning. Project Management Journal, 40(4), 94-103.

[19] Thompson, J. L. (2012). Why are Projects Late? Everything, but the Project Management Method is challenged!

[20] Ambituuni, A. (2011). Five Causes of Project Delay and Cost Overrun, and Their Mitigation

[21] IBM. (2008). Making Change Work. New York: IBM.

[22] Flyvbjerg, B., \& Budzier, A. (2011, September). Why Your IT Project May Be Riskier Than You Think. Retrieved February 20, 2015, from Harvard Business Review: https://hbr.org/2011/09/why-your-it-projectmay-beriskier-thanyou-think/ar/1

[23] The Standish Group (TSG). (2013). Chaos Manifesto 2013; Think Big, Act Small. The Standish Group International, Incorporated.

[24] Bloch, M., Blumberg, S., \& Laartz, J. (2012, October). Delivering largescale IT projects on time, on budget, and on value. Retrieved January 31, 2015, from McKinsey \& Company.

[25] PwC. (2012). Insights and Trends: Current Portfolio, Program, and Project Management Practices (The third global survey on the current state of project management). PwC.

[26] Wayngaad, C., Pretorius, J. C., \& Pretorius, L. (2012). Theory of the Triple Constraint- A Conceptual Review. Proceedings of the 2012 IEEE IEEM, (pp. 1991-1997).

[27] PMI. (2015). What is Project Management? Retrieved March 29, 2015, from Project Management Institute: http://www.pmi.org/AboutUs/About-Us-What-is-ProjectManagement.aspx

[28] Catanio, J. T., Armstrong , G., \& Tucker, J. (2013, February). Project Management Certification and Experience: The Impact on the Triple Constraint. Journal of Advances in Information Technology, VOL. 4, NO. 1, pp. 8-19.

[29] Dobson, M. S. (2004). The Triple Constraints in Project Management. Virginia: Management Concepts.

[30] Dobson, M., \& Feickert, H. (2007). The Six Dimensions of Project Management: Turning Constraints into Resources. Vienna: Management Concepts, Inc.

[31] Wayngaag, C. J., Pretorius, J.-H. C., \& Pretorius, L. (2011). Effective Management of the Triple Constraint Through Polarity Management Techniques- A Refreshed Perspective. Johannesburg: University of Johannesburg. 